\title{
ORNITHOLOGY
}

\section{Birds of Saskatchewan}

Edited by Alan R. Smith, C. Stuart Houston, and J. Frank Roy. 2019. Nature Saskatchewan. 765 pages, 79.95 CAD, Cloth.

For over three-quarters of a century, Nature Saskatchewan (formerly the Saskatchewan Natural History Society) has promoted investigation of the natural history of the province and surrounding areas by both amateurs and professionals. Many of the results have appeared in the quarterly Blue Jay, and

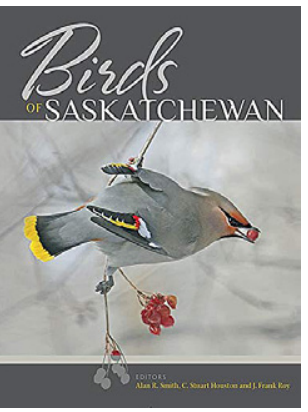
in the Society's many Special Publications. Birds have been the focus of much of this work. Birds of Saskatchewan is the culmination of these efforts. It began as the dream of the late Manley Callin (19111985). His bequest helped fund its production and his dream is fulfilled by more than a decade of effort by the three editors, 107 authors of one or more species accounts, 69 photographers, and 24 reviewers.

Readers will find much of interest and value on every page of this large book $(30 \times 23 \mathrm{~cm} ; 3 \mathrm{~kg})$. The 437 accounts cover all species occurring regularly in the province, plus extinct, accidental, and hypothetical species. There is much more than just species accounts in this book. The first section is an "Introduction to the Province". It begins with a presentation of the seven "Natural Vegetation Zones in Saskatchewan", describing their natural flora and listing their typical and special bird species. One or more beautiful photos illustrate each zone and give lie to the common belief that the province has nothing but flat wheat fields. "Human History and the Flora and Fauna of Saskatchewan" reviews the influence of humans on the plants and animals, especially since the beginning of European settlement in 1872. It describes the negative impacts of human activity such as agriculture and resource extraction on many avian species, and the positive effects on species that have invaded or prospered in response to such activity. Efforts to protect and sustain bird populations are described, from the establishment of the first bird sanctuary in North America at Last Mountain Lake in 1887 to recent concerns about the federal government's divestiture of the Prairie Farm Rehabilitation Administration pastures and its impact on populations of threatened grassland bird species. "The Ornithological History of Saskatchewan" begins with Henry Kelsey's 1690 observation of Passenger Pigeons and Sir John Richardson's ornithological collections in 1827. A "who's who" of professional ornithologists (John Macoun, A.C. Bent, Francis Harper, W.E. Clyde Todd, George M. Sutton, W. Earl Godfrey, and J. Dewey Soper, among others) visited the province between 1880 and 1947. Their specimens are found in many of the major museums in North America. The roles of resident naturalists, bird banders, and institutions and organizations such as the Royal Saskatchewan Museum and Nature Saskatchewan are reviewed briefly. The section ends with a description of a century of "citizen science" which has contributed greatly to this book through Christmas Bird Counts (CBC), the Prairie Nest Records Scheme (PNRS), Breeding Bird Surveys (BBS), and through recent electronic activities such as Saskbirds (https://twitter.com/hashtag/saskbirds) and eBird (https://ebird.org/home).

Accounts for species that occur regularly in the province are about four pages in length, and packed with information. Each begins with a brief introduction to the species and a description of the North American range. A small map of the province is colour-coded to indicate seasonal distribution. "History" summarizes records prior to extensive settlement (1924). "Status" reviews relative abundance and population trends based on BBS data and the Committee on the Status of Endangered Wildlife in Canada (COSEWIC) designation, where appropriate. Sections on "Spring", "Breeding", "Fall", and "Winter" summarize information on migration dates and breeding records. The final sections describe "Saskatchewan Research" and "Banding" (including names of banders with the number banded and recoveries). One to five photos showing plumages, nests, young, and, in many cases, behaviour, illustrate each account. Accounts for permanent residents and winter visitors include a table summarizing CBCs for different vegetation zones. Accounts for common waterfowl species include maps illustrating the recoveries of birds banded in the province, clearly demonstrating the role of Saskatchewan as the "duck factory" of North America. Accounts for accidental (44) and hypothetical (42) species are a half-page or less in length. They summarize records for accidentals and available evidence for species whose occurrence in 
Saskatchewan has not been documented with photographs or sound recordings.

Most of the accounts include a shaded "Interest Box". Some provide special information (e.g., a short biography of Bernard Rogan Ross, for whom Ross's Goose and Gull were named) or give taxonomic information (e.g., the convoluted history of the scientific name for the Olive-sided Flycatcher). However, most recount specific experiences that contributors have had with the species in question. The late L.B. Potter describes (in the 1922 volume of The Canadian FieldNaturalist) the abundance of Sage-grouse in southwestern Saskatchewan in the first decades of the 20th century. He notes a tameness which led them to trespass into the garden and eat the lettuce plants. Editor Alan Smith remembers a night in the 1960s that he spent sleeping on the prairie wool at the Matador Field Station, only to be woken in the early morning by a Vesper Sparrow who landed on his hip and used him as a song perch. Such vignettes capture the pleasures, rewards, and memories that we all derive from our activities in the natural world.

Special mention must also be made of the photographs that grace almost every page of this book. Many of these are nothing short of spectacular-it would be impossible to select a favourite! The Bohemian Waxwing on the cover is a good example. The photographers and the Photo Selection Committee deserve congratulations for their efforts.

Eight appendices follow the species accounts and cover various topics, including a list of bird banders mentioned in the accounts, a summary of results of CBCs from 1913 to 2016, a map of BBS localities (none in the northern third of the province), and a useful gazetteer of place names mentioned in the accounts. Appendix B includes biographical sketches of 168 now-deceased individuals who contributed to our knowledge of Saskatchewan ornithology. It includes explorers, early collectors, and professional ornithologists who have worked in the province. But most contributors were farmers, ranchers, teachers, physicians, accountants, homemakers, etc. who shared a common love of natural history and birds. On almost every page, I found the name of someone who encouraged or supported a bird-crazy teenager on my path to a career in ornithology. I know that many others of my cohort (including the senior editor) shared this experience, and that it continues today, guaranteeing that Saskatchewan ornithology will thrive in the 21 st century.

The book ends with a "Literature Cited" section spanning 49 pages and including approximately 2500 entries (my estimate)! I suspect that there few (if any) publications relevant to the avifauna of Saskatchewan that have been overlooked. Future researchers now have a single place to access relevant citations covering information on observations and research from 1690 to 2016.

Birds of Saskatchewan is an important record of the history and current state of the avian fauna of the province. It brings together a wealth of information that will be useful to both bird enthusiasts and future scholars. Beyond that, it is a delight to move through the pages, sampling both the data and the biological details contained. Its price is well worth the rewards of exploring a remarkable book.

M. Ross LeIN University of Calgary, Calgary, AB, Canada 